\title{
Correlation of antiangiogenic, antioxidant and cytotoxic activities of some Sudanese medicinal plants with phenolic and flavonoid contents
}

\author{
Loiy Elsir A Hassan 1,2, Mohamed B Khadeer Ahamed', Aman S Abdul Majid ${ }^{3}$, Hussein M Baharetha ${ }^{1,4}$, \\ Nahdzatul S Muslim', Zeyad D Nassar ${ }^{5}$ and Amin MS Abdul Majid ${ }^{1 *}$
}

\begin{abstract}
Background: Consumption of medicinal plants to overcome diseases is traditionally belongs to the characteristics of most cultures on this earth. Sudan has been a host and cradle to various ancient civilizations and developed a vast knowledge on traditional medicinal plants. The present study was undertaken to evaluate the antioxidant, antiangiogenic and cytotoxic activities of six Sudanese medicinal plants which have been traditionally used to treat neoplasia. Further the biological activities were correlated with phytochemical contents of the plant extracts.

Methods: Different parts of the plants were subjected to sequential extraction method. Cytotoxicity of the extracts was determined by dimethylthiazol-2-yl)- 2,5diphenyl tetrazolium bromide (MTT) assay on 2 human cancer (colon and breast) and normal (endothelial and colon fibroblast) cells. Anti-angiogenic potential was tested using ex vivo rat aortic ring assay. DPPH (1,1-diphenyl-2-picrylhydrazyl) assay was conducted to screen the antioxidant capabilities of the extracts. Finally, total phenolic and flavonoid contents were estimated in the extracts using colorimetric assays.

Results: The results indicated that out of 6 plants tested, 4 plants (Nicotiana glauca, Tephrosia apollinea, Combretum hartmannianum and Tamarix nilotica) exhibited remarkable anti-angiogenic activity by inhibiting the sprouting of microvessels more than $60 \%$. However, the most potent antiangiogenic effect was recorded by ethanol extract of T. apollinea (94.62\%). In addition, the plants exhibited significant antiproliferative effects against human breast (MCF-7) and colon (HCT 116) cancer cells while being non-cytotoxic to the tested normal cells. The $I C_{50}$ values determined for C. hartmannianum, N. gluaca and T. apollinea against MCF-7 cells were 8.48, 10.78 and $29.36 \mathrm{\mu g} / \mathrm{ml}$, respectively. Whereas, the $\mathrm{IC}_{50}$ values estimated for $\mathrm{N}$. gluaca, T. apollinea and C. hartmannianum against HCT 116 cells were 5.4, 20.2 and $27.2 \mu \mathrm{g} / \mathrm{ml}$, respectively. These results were more or less equal to the standard reference drugs, tamoxifen $\left(I C_{50}=6.67 \mu \mathrm{g} / \mathrm{ml}\right)$ and 5-fluorouracil $\left(I C_{50}=3.9 \mu \mathrm{g} / \mathrm{ml}\right)$ tested against MCF-7 and HCT 116, respectively. Extracts of C. hartmannianum bark and N. glauca leaves demonstrated potent antioxidant effect with $I_{50 \text { s }}$ range from 9.4-22.4 and $13.4-30 \mu \mathrm{g} / \mathrm{ml}$, respectively. Extracts of $\mathrm{N}$. glauca leaves and Tapollinea aerial parts demonstrated high amount of flavonoids range from 57.6-88.1 and 10.7-78 mg quercetin equivalent/g, respectively.
\end{abstract}

Conclusions: These results are in good agreement with the ethnobotanical uses of the plants (N. glauca, T. apollinea, C. hartmannianum and T. nilotica) to cure the oxidative stress and paraneoplastic symptoms caused by the cancer. These findings endorse further investigations on these plants to determine the active principles and their mode of action. Keywords: Antiangiogenesis, Raorta ring assay, Antioxidants, Anticancer, Sudanese medicinal plants, Traditional medicine

\footnotetext{
* Correspondence: aminmalikshah@gmail.com

'EMAN Research and Testing Laboratory, School of Pharmaceutical Sciences, Universiti Sains Malaysia, Penang, Malaysia

Full list of author information is available at the end of the article
} 


\section{Background}

Cancer is a major public health burden in both developed and developing countries. The International Agency for Research on Cancer (IARC), the specialized cancer agency of the World Health Organization reported that about 14.9 million cancer cases were estimated around the world in 2013, of these 7.7 million cases were in men and 6.9 million in women and further this number is expected to increase to 24 million by 2035 [1]. Treating cancer has become a major challenge as there is no single effective treatment that works for all types of cancer. Most of conventional chemotherapy regimens which employ different combinations of cytotoxic drugs which are often associated with serious side effects and chemoresistance. Conventional therapy has also become less favorable in the mindset of sufferers and as a result many patients resort to seeking alternative treatments [2]. The resistance of metastatic cancerous cells to chemotherapy and its adverse effects has become a serious challenge in cancer research. Despite the intensive progress in chemotherapeutics in the last decades, the need to discover and to develop new, alternative, or adjuvant therapeutic agents remains.

Botanicals have long been used traditionally in treatment of various types of cancers [3] and often less associated with the side effects like the modern chemotherapy has [4]. Realizing the potential benefits of botanicals as a source of active anticancer compounds, the National Cancer Institute (U.S.A) collected about 35,000 plant samples from 20 countries and has screened around 114,000 extracts for anticancer activity [5]. Out of the 92 anticancer drugs marketed prior to 1983 in US and among the ones sold worldwide between 1983 and 1994, 60\% are of natural origin [6]. This includes natural products, derivatives of natural products or semi-synthetic pharmaceuticals based on natural products models [7].

Angiogenesis is the sprouting of new blood vessels from pre-existing vessels and is strongly implicated in solid tumorgenesis, proliferative retinopathies, obesity and rheumatoid arthritis [8]. Tumor angiogenesis is the consequence of an angiogenic imbalance in which proangiogenic factors predominate over antiangiogenic factors. Furthermore, angiogenesis is essential for growth and metastasis of malignant tumors. Vascular Endothelial Growth Factor-A (VEGF-A) is believed to be a critical angiogenic mitogen [9]. Therefore, tumor angiogenesis can be considered as an important pharmacological target for cancer prevention and treatment [10,11]. Consequently, this hypothesis has paved a pathway for the development of the cutting edge therapeutic technology called angiotherapy. Anti-angiogenic approach can overcome the cytotoxic adverse effects and chemoresistant problems associated with the classical chemotherapies. Anti-angiognenic drugs work by inhibiting the synthesis of new blood vessels that supply blood, nutrients and oxygen to growing tumor. Previous reports of Avastin, a monoclonal antibody for VEGF, and fluorouracil-based combination therapy showed a significant improvement in survival of patients with metastatic colorectal carcinoma [12]. However conventional antiangiogenic compounds based on monoclonal antibody technology may have limitations from the cost point of view. Plant sources of antiangiogenic compounds have been explored as they are more economical to produce in large scale [13]. However at present there are no plant based antiangiogenic compounds available commercially in the market.

Plants have many phytochemicals which are potential source of natural antioxidants, such as phenolic diterpenes, flavonoids, tannins and polyphenolic acids [14] with versatile biological activities. Plant polyphenolics have been recognized as the potential therapeutic agents targeting cancer, pathological angiogenesis and cardiovascular disease in the next decade $[15,16]$. These benefits have been attributed to the presence of antioxidantrich polyphenolic compounds [16,17].

The use of traditional medicine especially medicinal plants in Sudan is still the main alternative therapy which is based entirely on the indigenous knowledge gained from ancestral experience. Although, there is an important local ethno botanical biography describing the most frequently used plants in treatment of various clinical conditions however, very few have been studied scientifically for chemometric analysis of the medicinal herbs to identify the active principles. The vast majority is still unexplored phytochemically and their medicinal properties have not yet validated [18].

Compelling data implicate angiogenesis and tumorassociated neovascularization as a central pathogenic step in the process of tumor growth, invasion and metastasis. Subsequently, it was shown that a significant correlation existed between the degree of tumor angiogenesis (micro vessel density) and survival in patients presenting with lymph node-negative breast carcinoma [19]. Therefore, it comes to handy that targeting tumor angiogenesis using antiangiogenic agents the blood vessels which supply the tumor with nutrients and oxygen, in turn it could lead to halt tumor growth and metastasis.

With this background, the present study was undertaken to analyze the antiangiogenic, antioxidant and cytotoxic properties of 32 extracts prepared from six Sudanese plants; Indigofera spinosa Forsk. (Leguminosae), Nicotiana glauca var. (Solanaceae), Tephrosia apollinea (Del.) Link (Leguminosae), Tamarix nilotica (Ehrenb.) Bunge (Tamaricaceae), Combretum hartmannianum Schweinf. (Combretaceae) and Capparis decidua (Forsk.) Edgew (Capparaceae). This study is the first to report the antiangiogenic properties of these selected Sudanese medicinal plants and correlated the activity with antioxidant 
property. In addition, an investigation on the cytotoxicity of the extracts was conducted to identify the potential source of antineoplastic agents.

\section{Methods}

\section{Plant material}

Six Sudanese medicinal plants, I. spinosa, N. glauca, T. apollinea, T. nilotica, C. hartmannianum and C. decidua were selected for the study. Plant material was collected during the period of March-July 2013 except C. hartmaniunum which was collected during March 2014 from Elgadarif City - Sudan. The taxonomic authentication of all the plants was carried out at The Medicinal and Aromatic Plants Research Institute, National Center for Research by Dr. Wail Alsadig. Voucher specimens (voucher references numbers: MAPRI/NB-53a-g) were deposited at the herbarium of the institute.

\section{Preparation of extracts}

The plant materials were dried in oven $\left(35-40^{\circ} \mathrm{C}\right)$ and powdered mechanically. The pulverized plant material $(50 \mathrm{~g})$ was subjected to sequential extraction method started with n-hexane and followed by ethanol, methanol and water. All the extracts were prepared by $250 \mathrm{ml}$ of the solvents using hot maceration $\left(40^{\circ} \mathrm{C}\right)$ method with intermittent shaking. The extracts were filtered and concentrated at $45^{\circ} \mathrm{C}$ under vacuum by rotary evaporator (Buchi, USA) and further dried overnight at $45^{\circ} \mathrm{C}$. Stock solutions of the extracts were prepared at $10 \mathrm{mg} / \mathrm{ml}$ in $100 \%$ dimethyl sulfoxide (DMSO). Further serial dilution of the stock was performed with cell culture media to obtain a range of desired concentrations of the extracts. All solvents used in this study were of analytical grade.

\section{Experimental animals}

Twelve to fourteen weeks old healthy Sprague Dawley male rats were used. To avoid physiological variations that could affect the process of angiogenesis in female rats due to estrous cycle, only male rats were used in rat aortic ring assay. The animals obtained from animal house facility of Universiti Sains Malaysia (USM) and were kept for one week in animal transit house (School of Pharmaceutical Sciences, USM) prior to the experiments. The animals were kept in well ventilated cage with food and water provided. The animals were euthanized using $\mathrm{CO}_{2}$ and dissected to excise thoracic aorta. All procedures were carried out according to the guidelines of Animal Ethics Committee USM. The present study was submitted to the institutional animal ethics committee, "Animal Ethics Committee USM" for evaluation and the present study is approved by the committee (approval Reference number: PPSG/07 (A)/044/(2010) (61)).

\section{Chemicals and reagents}

Cell culture reagents were purchased from Gibco, USA; RPMI 1640 medium; catalogue number (A10491-01), Dulbecco's Modified Eagle Medium; Catalogue number (31100-035) were obtained from GIBCO, UK. Phosphate buffered saline, trypsin, heat inactivated foetal bovine serum (HIFBS), penicillin/streptomycin (PS), fibrinogen, aprotinin, thrombin, suramin, aprotinin, 6-Aminocaproic acid, L-glutamine, thrombin and gentamicin were purchased from Sigma, Germany. MTT (3-(4,5-Dimethylthiazol-2-yl)2,5diphenyl tetrazolium bromide) was procured from Sigma-Aldrich, USA. Dimethyl sulfoxide (DMSO) was purchased from Fluka, USA.

\section{Cell lines and culture conditions}

Human Umbilical Vein Endothelial Cell line HUVEC (Passage No. 3), catalogue number (C2517A); human colorectal carcinoma cell line HCT-116 (Passage No. 5), catalogue number (CCL-247); human hormone sensitive and invasive breast cancer cell line MCF-7 (Passage No. 4), catalogue number (HTB-22); human colorectal normal cell line CCD-18 (Passage No. 3), catalogue (CRL-1459) were purchased from ScienCell, USA. HUVEC were maintained in endothelial cell medium (ECM) (ScienCell, USA) supplemented with endothelial cell growth supplements (ECGS), $5 \%$ HIFBS and 1\% PS. HCT-116 cells were maintained in RPMI whereas, MCF-7 and CCD-18Co were maintained in DMEM medium. The media were supplemented with $5 \%$ heat inactivated fetal bovine serum and $1 \%$ penicillin/ streptomycin. Cells were cultured in a humidified incubator at $37^{\circ} \mathrm{C}$ supplied by $5 \% \mathrm{CO}_{2}$. Cell culture work was done in sterile conditions using Class II biosafety cabinet (ESCO, USA).

\section{Rat aorta ring assay}

This assay was carried out on rat aortic explants as previously described [20]. Thoracic aortas were removed from euthanized male rats, rinsed with serum free medium and cleaned from fibroadipose tissues. Totally 18 rats were used in this assay and approximately 12 to 14 rings (each ring is about $1 \mathrm{~mm}$ thickness) were prepared from an each aorta. The aortas were cross sectioned into small rings and seeded individually in 48-wells plate in $300 \mu \mathrm{L}$ serum free M199 media containing $3 \mathrm{mg} / \mathrm{ml}$ fibrinogen and $5 \mathrm{mg} / \mathrm{ml}$ aprotinin. Ten microliters of thrombin (50 NIH $\mathrm{U} / \mathrm{ml}$ in $1 \%$ bovine serum albumin in $0.15 \mathrm{M} \mathrm{NaCl}$ ) was added into each well and incubated at $37^{\circ} \mathrm{C}$ for $90 \mathrm{~min}$ to solidify. A second layer (M 199 medium supplemented with 20\% HIFBS, $0.1 \%$ 's-aminocaproic acid, 1\% L-Glutamine, $2.5 \mu \mathrm{g} / \mathrm{ml}$ amphotericin $\mathrm{B}$, and $60 \mu \mathrm{g} / \mathrm{ml}$ gentamicin) was added into each well $(300 \mu \mathrm{L} /$ well $)$. All the extracts were added at final concentrations of $100 \mu \mathrm{g} / \mathrm{ml}$. Suramin and $1 \%$ DMSO were used as positive and negative controls, respectively. On day four, the medium was replaced 
with a fresh one containing the test materials. On day five, aortic rings were photographed using EVOS f1 digital microscope (Advanced Microscopy Group, USA) (40× magnification) and subsequently the length of blood vessels outgrowth from the primary tissue explants was measured using Leica Quin software.

The inhibition of blood vessels formation was calculated using the formula;

$\%$ blood vessels inhibition $=[1-(\mathrm{A} 0 / \mathrm{A})] \times 100$, Where; $\mathrm{A} 0=$ distance of blood vessels growth in treated rings in $\mu \mathrm{m}, \mathrm{A}=$ distance of blood vessels growth in the control in $\mu \mathrm{m}$.

The results are presented as mean percent inhibition \pm SEM, $(n=8)$.

The significant difference between the microvessels out growth in treated versus untreated aortic rings was calculated using Student's t test. Based on the results of this assay, TAF273 was chosen for the subsequent investigations for the anti-angiogenic property.

\section{Cytotoxicity assay}

The MTT cytotoxicity assay was performed according to the method previously described [21]. Cells were seeded at $1.5 \times 10^{4}$ cells in each well of 96-well plate in $100 \mu \mathrm{l}$ of fresh culture medium and were allowed to attach for overnight. For screening, the cells (70 - 80\% confluency) were treated with the extracts at the final concentration of $50 \mu \mathrm{g} / \mathrm{ml}$. Later on, in order to obtain a doseresponse curve, the most active extracts were tested for cytotoxicity at $3.12,6.25,12.5,25,50$ and $100 \mu \mathrm{g} / \mathrm{ml}$ concentrations. After $48 \mathrm{~h}$ of the treatment the medium was aspirated and the cells were exposed to MTT solution prepared at $5 \mathrm{mg} / \mathrm{ml}$ in sterile PBS was added to each well at $10 \% \mathrm{v} / \mathrm{v}$ in the respective medium and was incubated at $37^{\circ} \mathrm{C}$ in $5 \% \mathrm{CO}_{2}$ for $3 \mathrm{~h}$. The water insoluble formazan salt was solubilized with $200 \mu \mathrm{l}$ DSMO/well. Absorbance was measured by infinite ${ }^{\bullet}$ Pro200 TECAN Group Ltd., (Switzerland) at primary wave length of $570 \mathrm{~nm}$ and reference wavelength of $620 \mathrm{~nm}$. Each plate contained the samples, negative control and blank. DMSO $(1 \% \mathrm{v} / \mathrm{v})$ was used as a negative control. 5-fluorouracil, Tamoxifen and Betulinic acid were used as standard reference control for HCT 116, MCF-7 and CCD-18Co cell lines, respectively. The assay was performed in quadricate and the results were presented as a mean percent inhibition to the negative control \pm SEM.

\section{Determination of total phenols}

Total phenols in the extracts were determined by a colorimetric method as described by Al-Suede and co-workers [22]. A stock of $1 \mathrm{mg} / \mathrm{ml}$ of extracts was prepared in methanol and $100 \mu \mathrm{l}$ of each extract was added separately to $750 \mu \mathrm{l}$ of Folin-Ciocalteau phenol reagent (1:10 diluted with double distilled $\mathrm{H}_{2} \mathrm{O}$ ). After 5 min incubation in the dark at room temperature, $750 \mu \mathrm{l}$ sodium bicarbonate solution $(60 \mathrm{~g} / \mathrm{l})$ was added and incubated at $30^{\circ} \mathrm{C}$ in the dark for $90 \mathrm{~min}$. The absorbance was measured at $725 \mathrm{~nm}$ using TECAN Multi-mode microplate reader Model Infinite $^{\oplus} 200$ (Mannedorf, Switzerland). Gallic acid was used $(5-80 \mu \mathrm{g} / \mathrm{ml})$ to construct the standard calibration curve. The results were expressed as Gallic acid equivalents per $100 \mathrm{mg}$ of extract (mg GAE/100 mg).

\section{Determination of total flavonoids}

The total flavonoids content in the extracts was determined using aluminum chloride colorimetric method with quercetin as standard [23]. A solution of $4 \mathrm{mg} / \mathrm{ml}$ of quercetin in methanol was prepared. Exactly, $500 \mu \mathrm{l}$ of different concentrations (3 to $200 \mu \mathrm{g} / \mathrm{ml}$ ) of the extracts were taken in separate test tubes. To each of the test tubes, $0.1 \mathrm{ml}$ of $10 \%(\mathrm{w} / \mathrm{v})$ aluminum chloride solution, $0.1 \mathrm{ml}$ of $1 \mathrm{M}$ potassium acetate solution, $1.5 \mathrm{ml}$ of methanol and $2.8 \mathrm{ml}$ of distilled water was added. The test tubes were thoroughly mixed and after incubation at room temperature for $30 \mathrm{~min}$, the absorbance reading of the reaction mixture was measured at $415 \mathrm{~nm}$ using a spectrophotometer (Perkin Lambda 45). A standard curve plotting all the different concentrations of quercetin standard was constructed and the total flavonoid content is expressed as micrograms of quercetin equivalent. The data were presented as mean $\pm \operatorname{SEM}(\mathrm{n}=6)$.

\section{DPPH scavenging effect}

DPPH (1,1-diphenyl-2-picrylhydrazyl) assay was carried out to evaluate the scavenging activity of the extracts [24]. The stock solution of DPPH was prepared at a concentration of $200 \mu \mathrm{M}$ in absolute methanol while stock solutions of the extracts were prepared at concentration of $10 \mathrm{mg} / \mathrm{ml}$. DPPH was dispensed into 96-well plate $(100 \mu \mathrm{l} /$ well $)$ and immediately, $100 \mu \mathrm{l}$ of test samples were added at final concentrations of $12.5,25,50,100$, $200 \mu \mathrm{g} / \mathrm{ml}$. Methanol alone and methanol with DPPH were used as blank and negative control, respectively. Ascorbic acid was used as positive control. The mixtures were incubated at $30^{\circ} \mathrm{C}$ for $30 \mathrm{~min}$ in the dark and then the absorbance was measured at $517 \mathrm{~nm}$ using TECAN microplate reader Model Infinite 200 (Mannedorf, Switzerland). The dose response curves were obtained and then used to calculate the median inhibitory concentration $\left(\mathrm{IC}_{50}\right)$. The results are expressed as mean \pm SEM $(n=6)$.

\section{Results}

\section{Plant extraction}

Four exacts were prepared from each plant material, starting with n-hexane followed by ethanol, methanol and water. The yield of each extract was calculated and presented in Table 1 as w/w percent yield. Among all the extracts, hexane extracts of all the tested plants 
Table 1 Parameters of different extracts of the selected Sudanese plants

\begin{tabular}{|c|c|c|c|c|c|}
\hline $\begin{array}{l}\text { Botanical } \\
\text { name }\end{array}$ & $\begin{array}{l}\text { Local } \\
\text { name }\end{array}$ & $\begin{array}{l}\text { Used } \\
\text { part }\end{array}$ & Solvent & Texture & Yield \% \\
\hline \multirow[t]{4}{*}{ Indgosfera spinosa } & \multirow[t]{4}{*}{ Hipatoheep } & \multirow[t]{4}{*}{ Stem } & n-Hexane & Sticky & 0.8 \\
\hline & & & Ethanol & Solid & 2.82 \\
\hline & & & Menthol & Solid & 1.72 \\
\hline & & & Water & Powder & 3.36 \\
\hline \multirow[t]{8}{*}{ Nicotiana gluaca } & \multirow[t]{8}{*}{ Hili leasa } & \multirow[t]{4}{*}{ Leaves } & n-Hexane & Sticky & 7.8 \\
\hline & & & Ethanol & Gummy & 11.73 \\
\hline & & & Menthol & Gummy & 4.11 \\
\hline & & & Water & Powder & 1.698 \\
\hline & & \multirow[t]{4}{*}{ Stem } & n-Hexane & Gummy & 0.82 \\
\hline & & & Ethanol & Gummy & 6.21 \\
\hline & & & menthol & Gummy & 3.94 \\
\hline & & & water & Powder & 5.94 \\
\hline \multirow[t]{4}{*}{ Tephrosia apollinea } & \multirow[t]{4}{*}{ Dhawasi } & \multirow{4}{*}{$\begin{array}{l}\text { Aerial } \\
\text { parts }\end{array}$} & n-Hexane & Gummy & 0.6 \\
\hline & & & Ethanol & Sticky & 2.41 \\
\hline & & & Menthol & Sticky & 5.86 \\
\hline & & & Water & Powder & 4.01 \\
\hline \multirow[t]{4}{*}{ Tamarix nilotica } & \multirow[t]{4}{*}{ Tarffa } & \multirow[t]{4}{*}{ Leaves } & n-Hexane & Gummy & 1.4 \\
\hline & & & Ethanol & Gummy & 12.64 \\
\hline & & & Menthol & Gummy & 4.14 \\
\hline & & & Water & Powder & 7.41 \\
\hline \multirow{8}{*}{$\begin{array}{l}\text { Combretum } \\
\text { hartmannianum }\end{array}$} & \multirow[t]{8}{*}{ El-Habeel } & \multirow[t]{4}{*}{ Leaves } & n-Hexane & Gummy & 7.16 \\
\hline & & & Ethanol & Sticky & 15.68 \\
\hline & & & Menthol & Gummy & 6.64 \\
\hline & & & Water & Powder & 6.04 \\
\hline & & \multirow[t]{4}{*}{ Bark } & n-Hexane & Gummy & 0.163 \\
\hline & & & Ethanol & Solid & 9.18 \\
\hline & & & Menthol & Solid & 3.37 \\
\hline & & & Water & Powder & 2.66 \\
\hline \multirow[t]{4}{*}{ Capparis decidua } & \multirow[t]{4}{*}{ Tunduli } & \multirow[t]{4}{*}{ Stem } & n-Hexane & Gummy & 0.892 \\
\hline & & & Ethanol & Gummy & 6.81 \\
\hline & & & Menthol & & 3.37 \\
\hline & & & Water & Powder & 01.56 \\
\hline
\end{tabular}

produced the lowest yield except for $N$. gluaca leaves extract $(7.8 \%)$. On average, the ethanol extracts of the tested plants showed the highest yield followed by methanol and water extracts. For instance, the highest yield recorded was $15.68 \%$ for ethanol extract of $C$. hartmannianum leaves. Table 1 shows the list of plants and the parts used in this study.

\section{Inhibitory effect of the extracts on sprouting of microvessels in rat aortic explants}

This assay was performed as the primary assay to screen the antiangiogenic potential of the extracts. Figure 1A shows a massive sprouting of microvessels in the aortic explants of vehicle treated group (negative control). Plant extracts with more than $60 \%$ inhibition of sprouting of blood vessels were considered as active extracts. Table 2 depicts the antiangiogenic properties of plant extracts determined by rat aorta ring assay. Out of 32 extracts, 12 extracts from three plants namely $T$. apollinea, C. hartmannianum and T. nilotica showed potent (more than 60\%) inhibitory activity. The highest inhibition (100\%) was produced by ethanol extract of aerial parts of T. apollinea (Figure 1B), followed by water extracts of T. nilotica (Figure $1 \mathrm{C}$ ). Interestingly, all the extracts of C. hartmannianum (Figure 1D) stem bark displayed significant $(p<0.05)$ inhibition of micro-blood vessels with an order of ethanol (88.74\%) followed by menthol (86.68\%) and n-hexane (81.75\%). Moreover, methanol and ethanol extracts of $C$. hartmannianum leaves also demonstrated significant ( $p<0.01$ and $p<0.05$, respectively) antiangiogenic effect with 68.84 and $63.68 \%$, respectively. In addition, Figure 1E depicted the remarkable inhibitory effect on microvessel growth from the rat aortic explant treated with $T$. nilotica extract. These results were very much comparable with the positive control, suramin which demonstrated potent inhibition of microvessel growth (Figure 1F). Figure 1G graphically depicts the difference between the effects of the extracts and Suramin.

\section{Anti-proliferative effect of the extracts against cancer cells}

The MTT assay was used to screen the possible cytotoxic activity of 32 extracts against two human cancer cells lines (HCT-116 and MCF-7) and two normal cell lines (HUVEC and CCD-18Co). For screening, the cells were treated with the extracts at $50 \mu \mathrm{g} / \mathrm{ml}$ concentration. The extracts with more than $60 \%$ inhibition of cell proliferation were considered as active extracts. Hexane extracts of $N$. glauca leaves and stem exhibited the highest cytotoxicity on all the tested cell lines, while hexane and ethanol extracts of aerial part of $T$. apollinea showed selective antiproliferative effect against breast cancer cell line (MCF-7) with 87.20 and $86.94 \%$, respectively. The hexane extract of $C$. hartmannianum leaves potently inhibited the growth of both cancer cell lines (HCT-116 and MCF-7) with 80.03 and $95.76 \%$ anti-proliferative effect, respectively. Moreover, the ethanol extract of C. hartmannianum stem bark showed selective cytotoxicity towards MCF-7 with $76.79 \%$. Interestingly, all the extracts of C. hartmannianum showed poor cytotoxicity against the normal cell lines (Table 3). Further, the most active extracts were selected to study the dose response cytotoxic effect. The median inhibitory concentration $\left(\mathrm{IC}_{50}\right)$ values for the most active extracts and the respective standard reference drugs were calculated for all the tested cell lines and the values are given in Table 4. 

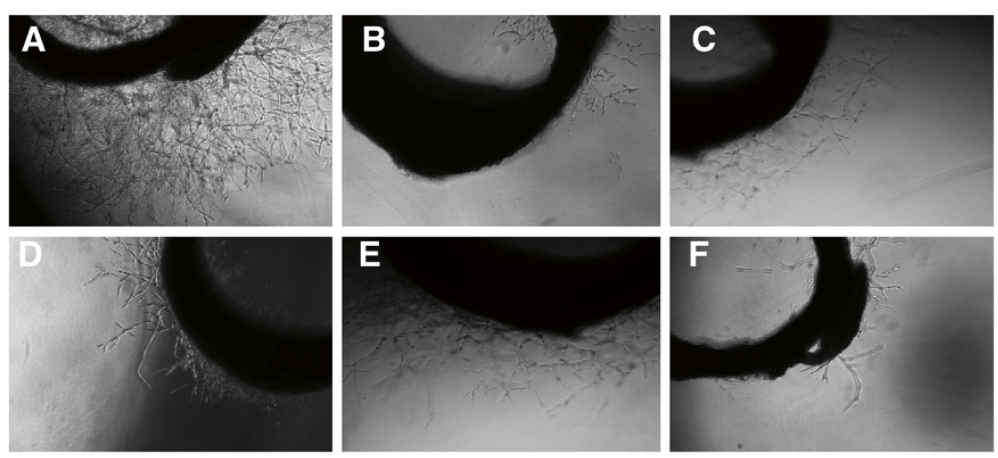

$\mathbf{G}$

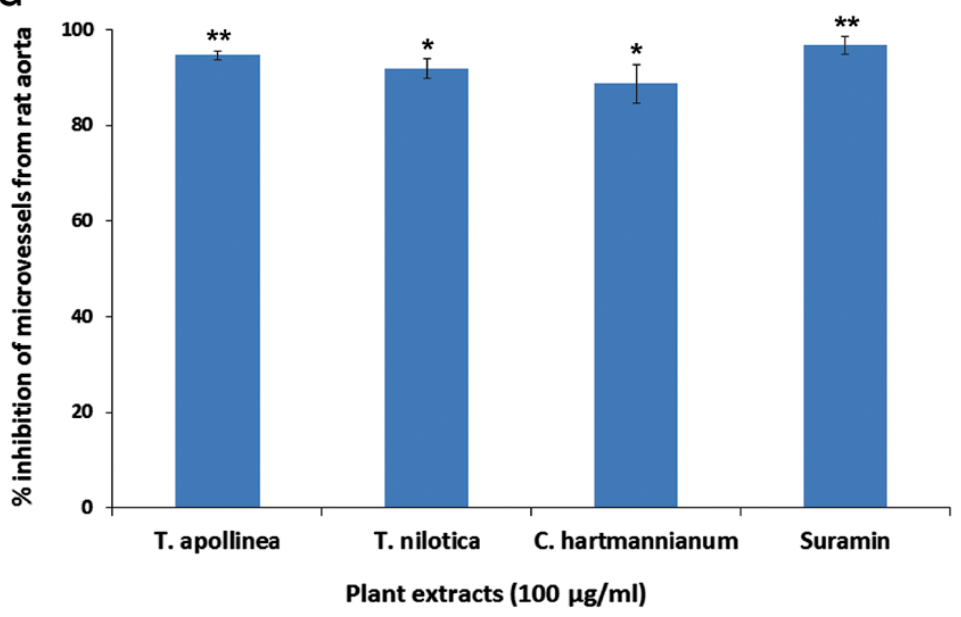

Figure 1 Antiangiogenic effect of selected Sudanese plants $(100 \mu \mathrm{g} / \mathrm{ml})$ against sprouting of microvessels in rat aortic explants.

A) Photomicrographic image of rat aortic ring of negative control showing extensive growth of microvessels. B) Photomicrographic image of rat aortic ring representative of polar extract of T. apollinea displaying potent inhibition of growth of microvessels. C) Treatment with $T$. nilotica showed significant inhibitory effect against sprouting of microvessels from rat aortic rings. D) Photomicrographic image of rat aortic explant treated with C. hartmannianum extract demonstrated considerable effect of antiangiogenicity. E) Photomicrographic image of rat aortic explant treated with non-polar extract of $T$. apollinea showing significant inhibitory effect on growth of microvessels. F) Photomicrographic image of rat aortic explant treated with standard reference, suramin exhibiting strong inhibitory effect on microvessels growth. G) Graphical representation of antiangiogenic activity of the active extracts obtained from the selected Sudanese plants. The values are expressed as mean \pm SEM $(n=10)$. ${ }^{* *} p<0.01$ and ${ }^{*} p<0.05$ compared to negative control group (0.1\% DMSO).

Table 2 Antiangiogenic activity of the selected Sudanese plants on rat aortic explants

\begin{tabular}{llll}
\hline Botanic name $^{\mathbf{n}}$ & Part used & Extract & Inhibition (\%) \\
\hline Tephrosia apollinea & Aerial parts & Ethanol & $94.6 \pm 1.8^{* *}$ \\
Tamarix nilotica & Leaves & Water & $91.7 \pm 2.2^{* *}$ \\
Combretum hartmannianum & Bark & Ethanol & $88.7 \pm 1.6^{*}$ \\
Combretum hartmannianum & Bark & Methanol & $86.6 \pm 3.8^{* *}$ \\
Combretum hartmannianum & Leaves & n-hexane & $81.7 \pm 1.7^{*}$ \\
Tephrosia apollinea & Aerial part & Methanol & $79.8 \pm 2.6^{*}$ \\
Tephrosia apollinea & Aerial parts & n-hexane & $73.1 \pm 1.5^{*}$ \\
Combretum hartmannianum & Bark & Water & $71.5 \pm 5.3^{*}$ \\
Tamarix nilotica & Leaves & Methanol & $65.5 \pm 2.9^{*}$ \\
Combretum hartmannianum & Leaves & Methanol & $68.8 \pm 2.2^{*}$ \\
Combretum hartmannianum & Leaves & Ethanol & $63.6 \pm 1.4^{*}$ \\
\hline
\end{tabular}

Results are presented as mean percent inhibition \pm S.D, $\mathrm{n}=3$.

Statistical significance is expressed as ${ }^{*}=P<0.05$, ${ }^{* *}=P<0.01$.
The results were comparable with the respective standard reference drugs, 5 -fluorouracil, betulinic acid and tamoxifen. Figures $2 \mathrm{~A}$ and $\mathrm{B}$ show the graphical illustration of the dose-dependent antiproliferative effect of the active extracts against human HCT 116 and MCF-7 cell lines.

Figure 3 shows the photomicrographic images of the treated HCT 116, MCF-7, CCD-18Co and HUVEC cell lines. The morphological feature of the treated cancer cells presented clear evidence of strong cytotoxicity of the extracts, as the vehicle (1\% DMSO) treated cells displayed a compact monolayer of aggressively growing cancer cells with prominent nuclei and intact cell membrane. Whereas the images taken from the extracts treated group showed a drastic reduction in the number of cells because of the anti-proliferative activity of the extracts. In addition, the extracts severely affected the pseudopodial projections of the cells which rendered the cells non-adherent and 
Table 3 Cytotoxic effect of different extracts of the selected Sudanese plants

\begin{tabular}{|c|c|c|c|c|c|c|}
\hline \multirow[t]{2}{*}{ Plants } & \multirow[t]{2}{*}{ Part used } & \multirow[t]{2}{*}{ Solvent used } & \multicolumn{4}{|c|}{$\%$ inhibition of cell proliferation } \\
\hline & & & HCT-116 & MCF-7 & $\mathrm{CCD}$ & HUVECs \\
\hline \multirow[t]{4}{*}{ Indgosfera spinosa } & Stem & n-Hexane & 27.79 & 40.43 & 4.16 & 5.64 \\
\hline & & Ethanol & 14.98 & 42.48 & 5.42 & 6.08 \\
\hline & & Methanol & 11.16 & 41.86 & 4.93 & 6.79 \\
\hline & & Water & 12.95 & 33.90 & 6.18 & 8.11 \\
\hline \multirow[t]{8}{*}{ Nicotiana gluaca } & Leaves & n-Hexane & 95.08 & 99.38 & 45.63 & 62.05 \\
\hline & & Ethanol & 49.66 & 81.10 & 38.57 & 36.25 \\
\hline & & Methanol & 19.83 & 75.58 & 10.15 & 22.64 \\
\hline & & Water & 17.20 & 49.81 & 8.09 & 19.79 \\
\hline & Stem & n-Hexane & 87.07 & 92.01 & 44.35 & 59.46 \\
\hline & & Ethanol & 33.58 & 49.28 & 32.63 & 25.43 \\
\hline & & Methanol & 43.47 & 53.51 & 40.47 & 27.87 \\
\hline & & Water & 28.95 & 57.53 & 38.56 & 19.89 \\
\hline \multirow[t]{4}{*}{ Tephrosia apollinea } & Aerial part & n-Hexane & 53.86 & 87.20 & 9.65 & 26.95 \\
\hline & & Ethanol & 46.91 & 86.94 & 7.88 & 16.28 \\
\hline & & Methanol & 47.43 & 87.09 & 10.23 & 18.91 \\
\hline & & Water & 16.86 & 25.60 & 4.68 & 5.79 \\
\hline \multirow[t]{4}{*}{ Tamarix nilotica } & Leaves & n-Hexane & 29.33 & 47.25 & 8.77 & 14.58 \\
\hline & & Ethanol & 7.8 & 46.61 & 5.83 & 22.89 \\
\hline & & Methanol & 19.61 & 46.14 & 6.65 & 17.35 \\
\hline & & Water & 6.93 & 28.47 & 3.87 & 11.68 \\
\hline \multirow[t]{8}{*}{ Combretum hartmannianum } & Leaves & n-Hexane & 80.03 & 95.76 & 7.75 & 16.62 \\
\hline & & Ethanol & 33.69 & 54.04 & 6.35 & 7.88 \\
\hline & & Methanol & 17.61 & 78.22 & 7.79 & 9.58 \\
\hline & & Water & 26.02 & 36.30 & 6.23 & 5.65 \\
\hline & Bark & n-Hexane & 26.30 & 42.43 & 5.74 & 6.61 \\
\hline & & Ethanol & 29.11 & 76.79 & 6.48 & 8.36 \\
\hline & & Methanol & 13.75 & 73.64 & 9.57 & 11.59 \\
\hline & & Water & 28.40 & 49.92 & 10.11 & 9.47 \\
\hline \multirow[t]{4}{*}{ Capparis decidua } & Stem & n-Hexane & 33.78 & 50.07 & 5.34 & 15.45 \\
\hline & & Ethanol & 8.5 & 41.99 & 3.69 & 5.77 \\
\hline & & Methanol & 14.76 & 39.87 & 5.58 & 19.57 \\
\hline & & Water & 21.82 & 54.41 & 6.76 & 4.38 \\
\hline
\end{tabular}

Table 4 IC ${ }_{50}(\mu \mathrm{g} / \mathrm{ml})$ values of the active extracts of the selected Sudanese plants

\begin{tabular}{|c|c|c|c|c|}
\hline \multirow[t]{2}{*}{ Extracts } & \multicolumn{2}{|c|}{ Carcinoma cell lines } & \multicolumn{2}{|c|}{ Normal cell lines } \\
\hline & HCT 116 & MCF-7 & HUVEC & CCD-18CO \\
\hline C. hartmannianum & 27.2 & 8.48 & 116.5 & 466.4 \\
\hline N. gluaca & 5.4 & 10.78 & 46.2 & 79.82 \\
\hline T. apollinea & 20.2 & 29.36 & 98.4 & 345.6 \\
\hline \multirow[t]{2}{*}{ Positive controls } & 5-Flourouracil & Tamoxifen & $\begin{array}{l}\text { Betulinic } \\
\text { acid }\end{array}$ & $\begin{array}{l}\text { Betulinic } \\
\text { acid }\end{array}$ \\
\hline & 3.9 & 6.67 & 88.4 & 128.9 \\
\hline
\end{tabular}

become round shaped. Interestingly, all the extracts studied showed either mild or negligible cytotoxicity towards the both normal (HUVEC and CCD-18Co) cell lines which were used as the model cell lines for the normal human cells.

\section{Total phenolic contents in the extracts}

The amount of total phenolic compounds present in each extract was determined from linear regression equation of calibration curve, $\left\{y=0.0034+0.0144\left(R^{2}=\right.\right.$ 0.9976) and expressed as Gallic acid equivalent in $\mathrm{mg} / \mathrm{ml}$ of extracts. Table 5 depicts the result of assessment of 

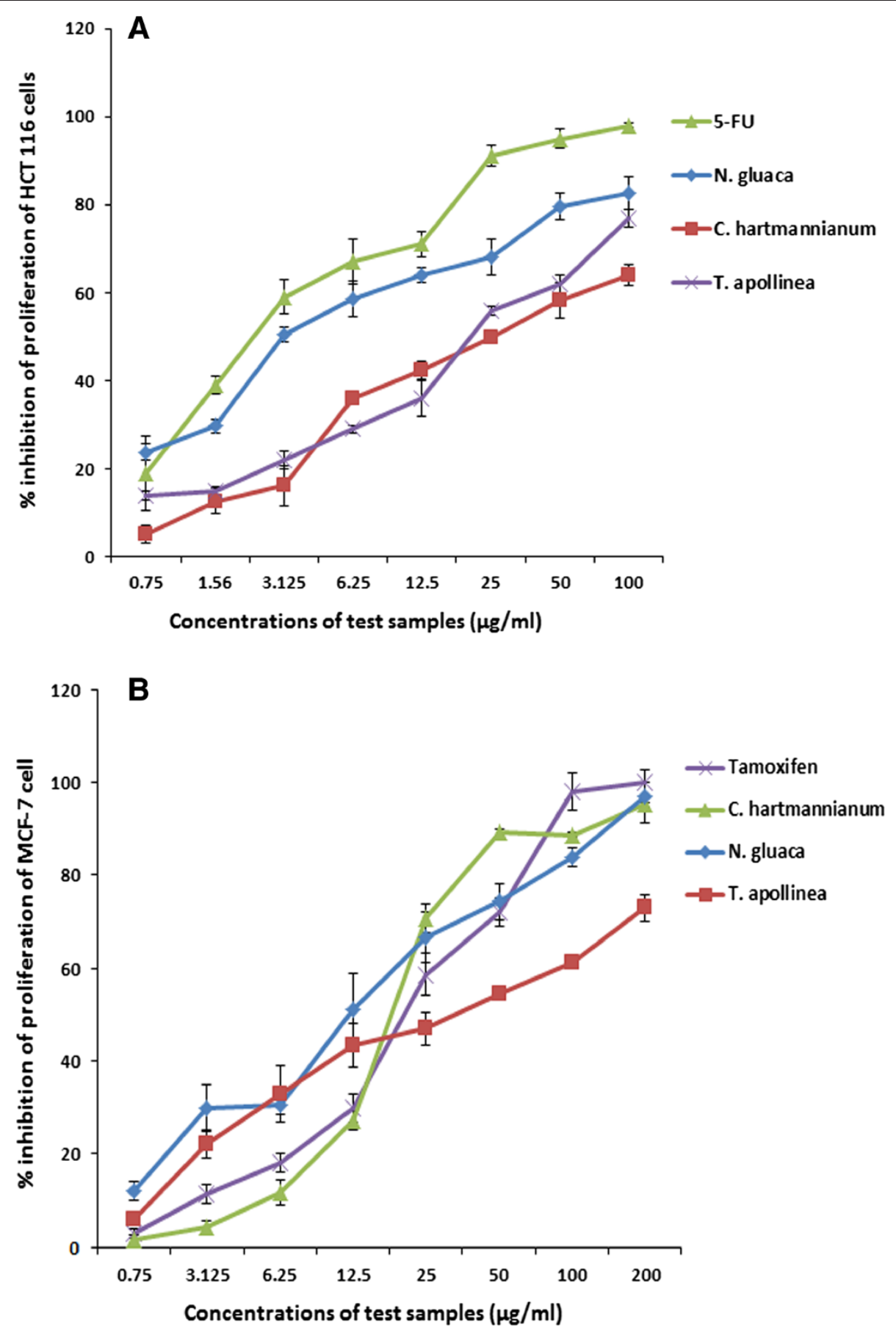

Figure 2 Dose dependent inhibitory effect of the active extracts of the selected Sudanese plants against HCT 116 (A) and MCF-7 (B) cell lines. The values are expressed as mean $\pm \operatorname{SEM}(n=6)$.

total phenolic contents in all the tested extracts. It is found that, hexane extracts of all the plants were deprived of total phenolic contents, either no or negligible amount of phenolic contents were detected in all hexane extracts. However, the methanol, ethanol and water extracts of the tested plants showed considerable level of phenolic contents. The results showed that, both stem bark and leaves of $C$. hartmannianum displayed high contents of total phenolics in which ethanol, methanol and water extracts showed 404.05 $\pm 0.06,96.56 \pm 0.05$ and $523.36 \pm 0.00 \mathrm{mg} \mathrm{GAE} / \mathrm{g}$, respectively for stem bark, whereas $169.19 \pm 0.02,392.83 \pm 0.01,268.21 \pm 0.03 \mathrm{mg}$ $\mathrm{GAE} / \mathrm{g}$, respectively for leaves. The results showed that methanol and water extracts of $T$. nilotica also 


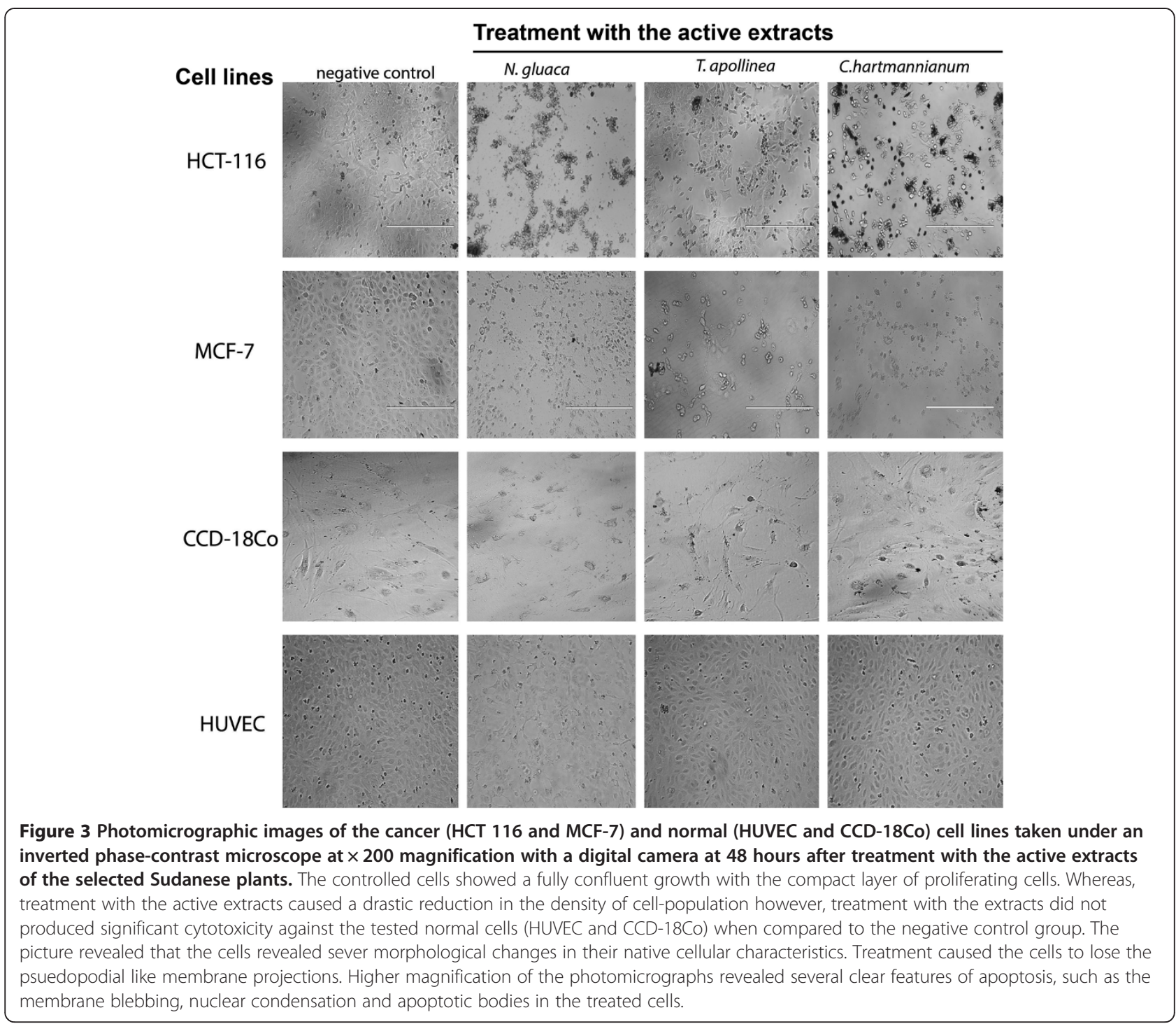

demonstrated significant $(p<0.05)$ level of phenolic contents with $333.96 \pm 0.01$ and $171.66 \pm 0.02 \mathrm{mg} \mathrm{GAE} / \mathrm{g}$, respectively. The leaves extracts of $N$. glauca showed moderate level of total phenolic contents (ethanol extract $=111.62 \pm$ $0.01 \mathrm{mg}$ GAE$/ \mathrm{g}$; methanol extract $=139.99 \pm 0.01 \mathrm{mg}$ $\mathrm{GAE} / \mathrm{g}$; water extract $=105.66 \pm 0.01 \mathrm{mg} \mathrm{GAE} / \mathrm{g}$ ).

\section{Total flavonoids contents in the extracts}

The total flavonoids contents in each extract were determined from linear regression equation of calibration curve obtained from the different concentrations of quercetin $\left[y=0.0032+0.0669\left(R^{2}=0.986\right)\right]$ and the results were expressed as mg quercetin equivalent/g of extracts (Table 5). Hexane extracts of all the tested plants and their parts showed higher content of flavonoids than compared to the other solvent extracts. However, on average all the extracts demonstrated considerably high amount of flavonoids in $N$. glauca leaves with hexane extract $=88.150 \pm 0.01 \mathrm{mg}$ quercetin equivalent $/ \mathrm{g}$, ethanol extract $=77.083 \pm 0.00 \mathrm{mg}$ quercetin equivalent $/ \mathrm{g}$, methanol extract $=64.583 \pm \mathrm{mg}$ quercetin equivalent $/ \mathrm{g}$ and water extract $=57.667 \pm \mathrm{mg}$ quercetin equivalent/g. Extracts of aerial parts of $T$. apollinea also showed significant level of flavonoids with hexane extract $=66.950 \pm 0.01 \mathrm{mg}$ quercetin equivalent $/ \mathrm{g}$, ethanol extract $=78.092 \pm 0.00 \mathrm{mg}$ quercetin equivalent $/ \mathrm{g}$, methanol extract $=10.708 \pm 0.01 \mathrm{mg}$ quercetin equivalent $/ g$ and water extract $=23.575 \pm 0.02 \mathrm{mg}$ quercetin equivalent/g. The total flavonoid contents measured in the extracts is given in the Table 5.

\section{DPPH scavenging effect of the extracts}

$\mathrm{IC}_{50}$ values of DPPH scavenging activity of the extracts is tabulated in Table 5. On average, the extracts prepared from methanol demonstrated the most potent antioxidant activity, whereas the extracts prepared from the solvent hexane displayed poor DPPH scavenging activity as the 
Table 5 Correlation between antioxidant activity of different extracts of selected Sudanese plants and the total content of flavonoids and phenolics in the extracts

\begin{tabular}{|c|c|c|c|c|c|}
\hline Plants & Part used & Solvent used & $\mathrm{DPPH}\left(\mathrm{IC}_{50}\right.$ in $\left.\mu \mathrm{g} / \mathrm{ml}\right)$ & Total flavonoids (mg/g) & Total phenolics $(\mathrm{mg} / \mathrm{g})$ \\
\hline \multirow[t]{4}{*}{ Indgosfera spinosa } & \multirow[t]{4}{*}{ Stem } & n-Hexane & $>1000$ & $28.1 \pm 0.00$ & ND \\
\hline & & Ethanol & 192.63 & $40.2 \pm 0.04$ & $115.4 \pm 0.01$ \\
\hline & & Methanol & 140 & $36.6 \pm 0.01$ & $161.4 \pm 0.03$ \\
\hline & & Water & $>1000$ & $13.3 \pm 0.01$ & $78.5 \pm 0.001$ \\
\hline \multirow[t]{8}{*}{ Nicotiana gluaca } & \multirow[t]{4}{*}{ Leaves } & n-Hexane & $>1000$ & $88.1 \pm 0.01$ & ND \\
\hline & & Ethanol & 54.76 & $77.1 \pm 0.00$ & $111.6 \pm 0.01$ \\
\hline & & Methanol & 13.437 & $64.5 \pm 0.002$ & $139.9 \pm 0.01$ \\
\hline & & Water & 30.05 & $57.6 \pm 0.001$ & $105.6 \pm 0.01$ \\
\hline & \multirow[t]{4}{*}{ Stem } & n-Hexane & $>1000$ & $58.6 \pm 0.02$ & $3.46 \pm 0.01$ \\
\hline & & Ethanol & 160.94 & $13.1 \pm 0.01$ & ND \\
\hline & & Methanol & 119.45 & $17.9 \pm 0.01$ & $41.02 \pm 0.003$ \\
\hline & & Water & 591.98 & ND & $12.5 \pm 0.02$ \\
\hline \multirow[t]{4}{*}{ Tephrosia apollinea } & \multirow[t]{4}{*}{ Aerial part } & n-Hexane & $>1000$ & $66.9 \pm 0.01$ & ND \\
\hline & & Ethanol & 120.22 & $78.1 \pm 0.00$ & ND \\
\hline & & Methanol & 48.803 & $10.7 \pm 0.01$ & $25.7 \pm 0.00$ \\
\hline & & Water & 2835.07 & $23.5 \pm 0.02$ & $23.5 \pm 0.01$ \\
\hline \multirow[t]{4}{*}{ Tamarix nilotica } & \multirow[t]{4}{*}{ Leaves } & n-Hexane & $>1000$ & $67.8 \pm 0.00$ & ND \\
\hline & & Ethanol & 880.70 & $13.1 \pm 0.04$ & $15.3 \pm 0.04$ \\
\hline & & Methanol & 12.62 & $24.9 \pm 0.02$ & $333.9 \pm 0.01$ \\
\hline & & Water & 67.53 & $22.6 \pm 0.001$ & $171.6 \pm 0.02$ \\
\hline \multirow[t]{8}{*}{ Combretum hartmannianum } & \multirow[t]{4}{*}{ Leaves } & n-Hexane & $>1000$ & 42. \pm 0.002 & ND \\
\hline & & Ethanol & 146.35 & $45.2 \pm 0.001$ & $169.2 \pm 0.02$ \\
\hline & & Methanol & 14.067 & $57.7 \pm 0.001$ & $392.8 \pm 0.01$ \\
\hline & & Water & 967.55 & $27.6 \pm 0.02$ & $268.2 \pm 0.03$ \\
\hline & \multirow[t]{4}{*}{ Bark } & n-Hexane & $>1000$ & $42.1 \pm 0.01$ & $1.9 \pm 0.01$ \\
\hline & & Ethanol & 9.47 & $28.1 \pm 0.02$ & $404.1 \pm 0.06$ \\
\hline & & Methanol & 28.91 & $24.2 \pm 0.02$ & $96.5 \pm 0.05$ \\
\hline & & Water & 22.47 & $29.7 \pm 0.01$ & $523.3 \pm 0.01$ \\
\hline \multirow[t]{4}{*}{ Capparis decidua } & \multirow[t]{4}{*}{ Stem } & n-Hexane & 212.56 & $67.5 \pm 0.02$ & $85.2 \pm 0.01$ \\
\hline & & Ethanol & 900.58 & $8.5 \pm 0.02$ & $19.9 \pm 0.01$ \\
\hline & & Methanol & 76.38 & $4.6 \pm 0.02$ & $40.3 \pm 0.2$ \\
\hline & & Water & $>1000$ & ND & $335.7 \pm 0.01$ \\
\hline
\end{tabular}

$\mathrm{ND}=$ Not Detected. The results are presented as mean \pm SEM. Each experiment was repeated three times; $(n=3)$.

$\mathrm{IC}_{50}$ values estimated to be more than $1000 \mu \mathrm{g} / \mathrm{ml}$. Among the tested plants, C. hartmannianum stem bark exhibited significant $(\mathrm{p}<0.01)$ antioxidant activity as lowest $\mathrm{IC}_{50}$ values were calculated for ethanol extract $\left(\mathrm{IC}_{50}=9.47 \mu \mathrm{g} / \mathrm{ml}\right)$, methanol extract $\left(\mathrm{IC}_{50}=28.91 \mu \mathrm{g} / \mathrm{ml}\right)$ and water extract $\left(\mathrm{IC}_{50}=22.47 \mu \mathrm{g} / \mathrm{ml}\right)$. Similarly, $N$. glauca leaves also demonstrated significant $(\mathrm{p}<0.05)$ antioxidant activity. The $\mathrm{IC}_{50}$ values for ethanol, methanol and water extracts of $N$. glauca leaves were calculated as 54.76, 13.437 and $30.05 \mu \mathrm{g} / \mathrm{ml}$, respectively. The other plants displayed either moderate or insignificant DPPH scavenging activity (Table 5).

\section{Discussion}

Increasing evidences in both experimental and clinical studies suggest that angiogenesis and oxidative stress play a cumulative role in the pathogenesis of malignancy. Angiogenesis, a process of formation of new blood vessel from pre-existing vessels, strongly implicates in the metastatic carcinogenesis. The role of reactive oxygen species (ROS) in tumorous angiogenesis has been extensively investigated and various connections have been established [25]. ROS can function as signaling molecules to mediate various angiogenic-related responses such as cell proliferation, differentiations and migration [26,27]. 
Natural anticancer medicines discovered from various medicinal systems that have been derived from traditional knowledge and practiced in many countries. Similarly, many herbal extracts and products are traditionally being used in Sudan for the treatment of cancer [28]. However, such medicinal plants have not gained clinical importance as botanicals due to the lack of systematic and scientific evidence presented through the suitable standard experimental procedures. In the present study six indigenous anticancer medicinal plants (I. spinosa, N. glauca, T. apollinea, T. nilotica, C. hartmannianum and $C$. decidua) from Sudan were studied. Since the people of Sudan have long been using these plants as either food or medicine, the plants considered as an integral part of the local pharmacopoeia. In the present study, different parts of the plants were selected to prepare 32 extracts using sequential extraction method with 4 solvents of different polarity. The rationale for performing extractions from non-polar to polar solvents is to confirm and validate the bio-efficacy in the aqueous extractions performed in the traditional manner in the form of tonics and aqueous pastes. In addition, the extracts with different polarities provide an idea about the specific phytochemical groups of the active principles present in the extracts.

This study aimed to evaluate the anti-carcinogenic activities of the 6 Sudanese medicinal plants and to correlate these activities with phytochemical analysis and antioxidant capability. Two assays were used to assess the anticarcinogenic properties of the plant extracts. One is the MTT assay which provides a simple method for determination of cell's viability via mitochondrial activity in living cells and other one is the rat aorta ring assay, which is based on the ability of the aortic wall to produce neovessels in bio-matrix gels after mechanical injury or angiogenic factor stimulation.

The results of rat aortic ring assay showed that, out of 6 tested plants, T. apollinea, C. hartmannianum and T. nilotica showed strong inhibitory effect (more than 60\%). Particularly, the ethanol extract of aerial parts of T. apollinea demonstrated highest anti-angiogenic activity by inhibiting $100 \%$ of the aortic microvessels. Noteworthily, all the extracts of C. hartmannianum displayed significant antiangiogenic activity.

Whereas, results of the cytotoxic assay showed that among all the extracts, the highly non-polar solvent extract i.e., hexane extract demonstrated higher cytotoxic activity than the other solvent extracts. Among the 6 plants, the hexane extracts of $N$. glauca leaves and stem bark exhibited most potent anti-proliferative effect on all the tested cancer cell lines. However, for the plant T. apollinea, both non-polar (hexane) and polar (ethanol) extracts displayed selective cytotoxicity towards hormone dependent breast cancer cell line (MCF-7). Consistently, again the extracts of C. hartmannianum leaves and stem bark exhibited strong inhibitory effect against the proliferation of HCT-116 and MCF-7 cells. Noteworthily, the extracts of the most effective plants ( $N$. glauca, T. apollinea and C. hartmannianum) did not produce significant cytotoxic effects against the normal cell lines (HUVEC and CCD-18Co).

Altogether, the most biologically active plants which showed significant antiangiogenic as well as cytotoxic activities were $N$. glauca, T. apollinea, C. hartmannianum and T. nilotica. These findings were further supported by the results of DPPH scavenging activity. The results showed that, most of the extracts of $C$. hartmannianum displayed strong DPPH quenching ability with lowest $\mathrm{IC}_{50}(9 \mu \mathrm{g} / \mathrm{ml})$, which was followed by $N$. glauca, T. nilotica and T. apollinea (Table 5).

The antiangiogenic and anti-proliferative effects of the plants may be due to their potential antioxidant activity, which further attributes to the collective contribution of phenolics and flavonoids present it the respective extracts. The findings of the present study revealed that these plants are enriched with phenolic and flavonoid contents than compared to the other plants which have shown less bio-efficacy. On average, the plants $N$. glauca, T. apollinea, C. hartmannianum and T. nilotica exhibited high antioxidant activity in DPPH free radical scavenging assay. This may support the traditional usage of these plants to improve complications such oxidative stress in cancer and other diseases. Many health beneficial effects of flavonoids are attributed to their ability to act as antioxidants. Research studies have shown that flavonoids as single electron donors can stabilize and scavenge the free radicals, which in conditions of oxidative stress may initiate angiogenesis or carcinogenesis. Similarly, phenolics have strong capability to interfere in a series of physiological events in biological systems, including those relating to oxidation processes [29].

Phenolics and flavonoids mostly found in plants are reported to have numerous biological effects including antioxidant, anti-neovascularization, antiproliferation and anticarcinogenic properties and are therefore considered for their important dietary roles as antioxidants and chemoprotective agents. Recently, intensive research has been focused on studying the naturally occurring phenolics and flavonoids that are able to decrease the generation of reactive oxygen species (ROS) in biological system. Oxidative stress contributed by ROS plays a critical role in the pathologies related with chronic disease such as cancer and excessive vascularization [30]. ROS-induced development of cancer involves malignant transformation due to DNA mutations and altered gene expression through epigenetic mechanisms which in turn leads to the uncontrolled proliferation of cancerous cells. Further, high levels of ROS are observed in various cancerous cells and a number of accumulating evidences [31-33] suggest that ROS function as key signaling molecules to stimulate 
various growth-related responses that eventually initiate angiogenesis and tumorigenesis [27]. Several studies demonstrated a significant role of phenolics in growth inhibition of breast, colon, prostate, ovary, endometrium and lung cancer cells [34,35].

The present study confirmed that the extracts of $N$. glauca, T. apollinea and C. hartmannianum demonstrated selective cytotoxicity towards human breast and colon cancer cell lines while being less cytotoxic against the normal cells. Such selective cytotoxic activity suggested that the active substances interact with special cancer-associated receptors or cancer cell special molecule, thus triggering some mechanisms that cause cancer cell death [36]. In observation under EVOS f1 digital microscope, typical apoptotic characteristics were observed, including cell membrane blebbing, loss of pseudopodia-like cellular projections, nuclear condensation, and separated apoptotic bodies (Figure 3). In addition, the treated MCF-7 cells displayed typical signs of apoptosis such as shrinkage of cells, chromatin condensation and crescent shaped nuclei (Figure 3, MCF-7 row). Several reports have revealed that flavonoids are able to inhibit the growth of cancer cells in vitro [37-39]. These findings are confirmed by several in vivo studies [40]. Flavonoids exert their anticancer action through affecting key mechanisms involved in cancer pathogenesis. Flavonoids are effective antioxidant and antiangiogenic agents. In initial stages, they inhibit metabolic activation of carcinogens. In progression phases they induce apoptosis, inhibit angiogenesis, cancer cell proliferation and tumor metastasis [41].

The magnitude of phenolic compounds in redox system acts either as reducing agents, hydrogen donators, singlet oxygen quenchers or in some cases as a metal chelating agents [42] thereby, the free radicals which generated in the metabolic pathways could be neutralized by phenolic compounds [43]. From the results obtained in this study, there is an obvious correlation between antiangiogenic and antioxidant activity, since the polyphenols inhibit the initiation and progression of angiogenesis [44-46]. Therefore, plant polyphenols may play an important role in halting angiogenesis, as well as have ability to prevent oxidant potentials of free radicals as natural source of antioxidants.

Results of the present study were completely in agreement with the study reported by Mariod et al., [47] on the various extracts of $C$. hartmannianum for its antioxidant property and total phenolic content. In the present study, C. hartmannianum demonstrated strong antiproliferative and antiangiogenic activities. It is reported that C. hartmannianum has strong capability to inhibit tyrosine kinase [48]. Tyrosine kinase is an important cellular signaling protein which has essential and critical role in several biological activities including cell proliferation and angiogenesis [49]. Several tyrosine kinase inhibitors such as, bevacizumab, sunitinib, sorafenib and pazopanib were recently approved for treatment of patients with malignant carcinoma [50,51]. In addition, many other anti-angiogenic tyrosine kinase inhibitors are being studied in phase I-III clinical trials in order to validate their beneficial anti-tumor, anti-metastatic and anti-angiogenic activities in human beings [52].

In this study, another herb that has shown a promising cytotoxicity on the tested cancer cell lines was $N$. glauca. Ibrahim and El-Sharkawy [53] reported the antioxidant activity and presence of phenolics and flavonoids in the leaves of $N$. glauca however, the present study reported that even stem bark extracts of the plant has remarkable antioxidant activity which could be attributed to the presence of high levels of phenolics and flavonoids in it.

The present study showed that both non-polar and polar extracts of aerial part of T. apollinea (Figure 3) exhibited selective antiproliferative effect against breast cancer cell line MCF-7. However, in our previous study [54] we reported the isolation of (-)-pseudosemiglabrin from aerial parts of $T$. apollinea and its antiproliferative activity on prostate, leukemia, breast and colon cancer cells. In the present study, the anticancer and antiangiogenic activities of nonpolar (hexane) extracts could be partly attributed to the high levels of flavonoid. It is well known that the plant-flavonoids demonstrated promising anticancer and antiangiogenic activities [55]. Several studies [56] reported the presence of complex prenylated flavones and phenolic compounds in $T$. apollinea and thus the antiangiogenic and antiproliferative properties of the herb recorded in the present study can be attributed to the cumulative effects of such bioactive constituents.

For the first time the present study reported the cytotoxic potentials of leaves of T. nilotica against human colon (HCT-116) and breast (MCF-7) cancer cells. However, the earlier reports mentioned that $T$. nilotica has selective cytotoxic potential against liver cell carcinoma (Huh-7), while being non-toxic to other cancer cells [57]. Nevertheless, the results of the present study agree in part with the previous findings [57] in the sense that $T$. nilotica has noticeable DPPH quenching capability. These findings are in agreement with some earlier reports [58,59] wherein, various types of phenolic constituents such as phenolic glyceride, phenolic lactone, phenolic aldehydes and dimeric phenols were isolated from the of T. nilotica.

Anti-angiogenic agent could target the cancer or endothelial cells at any of the steps necessary for carcinogenesis or neovascularization, such as proliferation, differentiation, migration, or tube formation [60]. Angiogenesis inhibitors act by actively promoting apoptosis in cells. In vitro and in vivo investigations have proved that many endogenous antiangiogenic compounds induce cytotoxicity via apoptotic cellular death [61].

The results of the present study could be very helpful as preliminary data in the search for new antitumor 
compounds from the tested Sudanese traditional medicinal plants. These plants have the potential to be chemically standardized and used as herbal medicines or developed into pharmaceutical drugs for the treatment of angiogenesis-dependent human ailments such as cancer and other hyperproliferative disorders. Bioassay-guided phytochemical and pharmacological studies are under investigation in an attempt to isolate and characterize the active constituents from the extracts of the plants which have shown promising antiangiogenic and anticancer properties.

\section{Conclusion}

In conclusion the present study revealed that among the six Sudanese medicinal plants tested, N. glauca, T. apollinea, C. hartmannianum and T. nilotica found to be most biologically effective herbs with significant antiangiogenic and antineoplastic effects. The biological activities observed in the study could be attributed to the antioxidant and higher phenolic and flavonoid contents of the plants. Furthermore, the extracts of these plants displayed either negligible or insignificant cytotoxicity against the tested human normal cells. Thus, these herbs could be considered as promising candidates for the development of novel chemopreventive or chemotherapeutic formulations with reduced side effects. The results obtained in the present study justify the traditional use of these medicinal plants to cure neoplasia. However, further studies to isolate the active compounds and to investigate the mode of action using in vivo xenograft experimental models are warranted against pathological neovascularization and tumor malignancy.

\section{Competing interests}

The authors declare that they have no competing interests.

\section{Authors' contributions}

AMSAM, MBKA, and LEAH designed the experiments. LEAH, HB and NSM carried out the phytochemical analysis. LEAH, NSM and ZDN performed the ex vivo antiangiogenic activity. LEAH, ZGN and HB participated in cytotoxic study on the plants. LEAH, MBKA, ASAM and AMSAM analyzed the data and interpreted the results. LEAH, MBKA and ASAM drafted the manuscript. All the authors read and approved the final manuscript.

\section{Acknowledgments}

We wish to acknowledge TWAS-USM (FR number: 3240240313) for the fellowship to LEAH and financial support for this research. In addition, the authors wish to acknowledge the support from Universiti Sains Malaysia for the research study through Research University Team (RUT) Grant No.: 1001/PFARMASI/851001.

\section{Author details}

'EMAN Research and Testing Laboratory, School of Pharmaceutical Sciences, Universiti Sains Malaysia, Penang, Malaysia. ${ }^{2}$ Department of Botany, Faculty of Science\& Technology, Omdurman Islamic University, P.O. Box 383, Omdurman, Sudan. ${ }^{3}$ Advanced Medical and Dental Institute (IPPT), Universiti Sains Malaysia, Penang, Malaysia. ${ }^{4}$ Department of Pharmacy, College of medicine and Health Sciences, Hadhramout University, Fuluk, Mukalla, Hadhramout, Republic of Yemen. ${ }^{5}$ School of Pharmacy, The University of Queensland, 20 Cornwall Street, Woolloongabba, QLD 4102, Australia.
Received: 23 July 2014 Accepted: 10 October 2014

Published: 20 October 2014

\section{References}

1. Bray F, Ren JS, Masuyer E, Ferlay J: Global estimates of cancer prevalence for 27 sites in the adult population in 2008. Int J Cancer 2013, 132(5):1133-1145.

2. Chorawala MR, Oza PM, Shah GB: Mechanisms of anticancer drugs resistance: an overview. Int J Pharma Sci Drug Res 2012, 1:01-09.

3. Cragg GM, Newman DJ: Plants as a source of anti-cancer agents. J Ethnopharmacol 2005, 100(1-2):72-79.

4. Jung Park E, Pezzuto J: Botanicals in cancer chemoprevention. Cancer Metastasis Rev 2002, 21(3-4):231-255.

5. Shoeb M: Anticancer Agents from Medicinal Plants. Pharmacology: Bangladesh Journal of; 2006:1(2006).

6. Newman DJ, Cragg GM: Natural products as sources of new drugs over the 30 years from 1981 to 2010. J Nat Prod 2012, 75(3):311-335.

7. Jaspars M, Lawton LA: Cyanobacteria - a novel source of pharmaceuticals. Curr Opin Drug Discov Devel 1998, 1(1):77-84.

8. Folkman J: What is the evidence that tumors are angiogenesis dependent? J Natl Cancer Inst 1990, 82(1):4-6.

9. Folkman J: Role of angiogenesis in tumor growth and metastasis. Semin Oncol 2002, 29(6, Supplement 16):15-18.

10. Scappaticci FA: The therapeutic potential of novel antiangiogenic therapies. Expert Opin Investig Drugs 2003, 12(6):923-932.

11. Dell'Eva R, Pfeffer U, Vené R, Anfosso L, Forlani A, Albini A, Efferth T: Inhibition of angiogenesis in vivo and growth of Kaposi's sarcoma xenograft tumors by the anti-malarial artesunate. Biochem Pharmacol 2004, 68(12):2359-2366.

12. Hurwitz H, Fehrenbacher L, Novotny W, Cartwright T, Hainsworth J, Heim W, Berlin J, Baron A, Griffing S, Holmgren E, Ferrara N, Fyfe G, Rogers B, Ross R, Kabbinavar F: Bevacizumab plus Irinotecan, Fluorouracil, and Leucovorin for Metastatic Colorectal Cancer. N Engl J Med 2004, 350(23):2335-2342.

13. Al-Suede FSR, Farsi E, Ahamed MKB, Ismail Z, Abdul Majid AS, Abdul Majid AMS: Marked antitumor activity of cat's whiskers tea (Orthosiphon stamineus) extract in orthotopic model of human colon tumor in nude mice. J Biochem Tech 2012, 5(28 December 2012):S170-S176.

14. Dawidowicz AL, Wianowska D, Baraniak B: The antioxidant properties of alcoholic extracts from Sambucus nigra L. (antioxidant properties of extracts). LWT Food Sci Technol 2006, 39(3):308-315.

15. Yoysungnoen $P$, Wirachwong $P$, Changtam $C$, Suksamrarn $A$, Patumraj $S$ : Anti-cancer and anti-angiogenic effects of curcumin and tetrahydrocurcumin on implanted hepatocellular carcinoma in nude mice. World J Gastroenterol 2008, 14(13):2003-2009.

16. Munzel T, Gori T, Bruno RM, Taddei S: Is oxidative stress a therapeutic target in cardiovascular disease? Eur Heart J 2010, 31(22):2741-2748.

17. Dell'Agli M, Buscialà A, Bosisio E: Vascular effects of wine polyphenols. Cardiovasc Res 2004, 63(4):593-602.

18. Galal M, Bashir AK, Salih AM, Adam SL: Activity of water extracts of Albizia Anthelmintica and A. lebek barks against experimenta Hymenolepis diminuta infection in rats. J Ethnopharmacol 1991, 33(1991):333-337.

19. Eatock MM, Schatzlein A, Kaye SB: Tumour vasculature as a target for anticancer therapy. Cancer Treat Rev 2000, 26(3):191-204.

20. Al-Salahi OSA, Kit-Lam C, Majid AM, Al-Suede FS, Mohammed Saghir SA, Abdullah WZ, Ahamed MB, Yusoff NM: Anti-angiogenic quassinoid-rich fraction from Eurycoma longifolia modulates endothelial cell function. Microvasc Res 2013, 90:30-39.

21. Ahamed MB, Aisha AF, Nassar ZD, Siddiqui JM, Ismail Z, Omari SM, Parish CR, Majid AM: Cat's whiskers tea (Orthosiphon stamineus) extract inhibits growth of colon tumor in nude mice and angiogenesis in endothelial cells via suppressing VEGFR phosphorylation. Nutr Cancer 2012, 64(1):89-99.

22. Al-Suede FSR, Khadeer Ahamed MB, Abdul Majid AS, Baharetha HM, Hassan LE, Kadir MOA, Nassar ZD, Abdul Majid AMS: Optimization of cat's whiskers tea (orthosiphon stamineus) using supercritical carbon dioxide and selective chemotherapeutic potential against prostate cancer cells. Evid Based Complement Alternat Med 2014, 2014:15.

23. Baharetha HM, Nassar ZD, Aisha AF, Khadeer AMB, Al-Suede FSR, Abd KMO, Zhari I, Abdul MAMS: Proapoptotic and antimetastatic properties of supercritical $\mathrm{CO} 2$ extract of Nigella sativa Linn. against breast cancer cells. J Med Food 2013, 16(12):1121-1130. 
24. Khadeer Ahamed MB, Krishna V, Dandin CJ: In vitro antioxidant and in vivo prophylactic effects of two gamma-lactones isolated from Grewia tiliaefolia against hepatotoxicity in carbon tetrachloride intoxicated rats. Eur J Pharmacol 2010, 631(1-3):42-52.

25. Gibellini L, Pinti M, Nasi M, De Biasi S, Roat E, Bertoncelli L, Cossarizza A: Interfering with ROS metabolism in cancer cells: the potential role of quercetin. Cancer 2010, 2(14 June 2010):1288-1311.

26. Coso S, Harrison I, Harrison CB, Vinh A, Sobey CG, Drummond GR, Williams ED, Selemidis S: NADPH oxidases as regulators of tumor angiogenesis: current and emerging concepts. Antioxid Redox Signal 2012, 16(11):1229-1247.

27. Ushio-Fukai M, Nakamura Y: Reactive oxygen species and angiogenesis: NADPH oxidase as target for cancer therapy. Cancer Lett 2008, 266(1):37-52

28. Hilmi Y, Abushama MF, Abdalgadir H, Khalid A, Khalid H: A study of antioxidant activity, enzymatic inhibition and in vitro toxicity of selected traditional sudanese plants with anti-diabetic potential. BMC Complement Altern Med 2014, 14(1):1472-6882

29. Balasundram N, Sundram K, Samman S: Phenolic compounds in plants and agri-industrial by-products: antioxidant activity, occurrence, and potential uses. Food Chem 2006, 99(1):191-203.

30. Kampa M, Nifli AP, Notas G, Castanas E: Polyphenols and cancer cell growth. Rev Physiol Biochem Pharmacol 2007, 159:79-113.

31. Yasuda M, Ohzeki Y, Shimizu S, Naito S, Ohtsuru A, Yamamoto T, Kuroiwa Y: Stimulation of in vitro angiogenesis by hydrogen peroxide and the relation with ETS-1 in endothelial cells. Life Sci 1999, 64(4):249-258.

32. Yeldandi AV, Rao MS, Reddy JK: Hydrogen peroxide generation in peroxisome proliferator-induced oncogenesis. Mutat Res 2000, 448(2):159-177.

33. Irani K, Xia Y, Zweier JL, Sollott SJ, Der CJ, Fearon ER, Sundaresan M, Finkel T, Goldschmidt-Clermont PJ: Mitogenic signaling mediated by oxidants in Ras-transformed fibroblasts. Science 1997, 275(5306):1649-1652.

34. Galati G, O'Brien PJ: Potential toxicity of flavonoids and other dietary phenolics: significance for their chemopreventive and anticancer properties. Free Radic Biol Med 2004, 37(3):287-303

35. Baghel SS, Shrivastava N, RS Baghel PA, Rajput S: A review of quercetin: antioxidant and anticancer properties. World J Pharm Pharmaceutical Sci 2012, 1(1):146-160.

36. Harada H, Noro T, Kamei Y: Selective antitumor activity in vitro from marine algae from Japan coasts. Biol Pharm Bull 1997, 20(5):541-546.

37. Moghaddam G, Ebrahimi SA, Rahbar-Roshandel N, Foroumadi A: Antiproliferative activity of flavonoids: influence of the sequential methoxylation state of the flavonoid structure. Phytother Res 2012, 26(7):1023-1028.

38. Delmulle L, Bellahcène A, Dhooge W, Comhaire F, Roelens F, Huvaere K, Heyerick A, Castronovo V, De Keukeleire D: Anti-proliferative properties of prenylated flavonoids from hops (Humulus lupulus L.) in human prostate cancer cell lines. Phytomedicine 2006, 13(9-10):732-734.

39. Chidambara Murthy KN, Kim J, Vikram A, Patil BS: Differential inhibition of human colon cancer cells by structurally similar flavonoids of citrus. Food Chem 2012, 132(1):27-34.

40. Batra P, Sharma A: Anti-cancer potential of flavonoids: recent trends and future perspectives. 3 Biotech 2013, 3(6):439-459.

41. Clere N, Faure S, Martinez MC, Andriantsitohaina R: Anticancer properties of flavonoids: roles in various stages of carcinogenesis. Cardiovasc Hematol Agents Med Chem 2011, 9(2):62-77.

42. Gordon MH: The Mechanism of Antioxidant Action in Vitro. In Food Antioxidants. Edited by Hudson BJF. Netherlands: Springer; 1990:1-18.

43. Miliauskas G, Venskutonis PR, van Beek TA: Screening of radical scavenging activity of some medicinal and aromatic plant extracts. Food Chem 2004, 85(2):231-237

44. Stoclet J-C, Chataigneau T, Ndiaye M, Oak MH, El Bedoui J, Chataigneau M, Schini-Kerth VB: Vascular protection by dietary polyphenols. Eur J Pharmacol 2004, 500(1-3):299-313.

45. Oak MH, El Bedoui J, Schini-Kerth VB: Antiangiogenic properties of natural polyphenols from red wine and green tea. J Nutr Biochem 2005, 16(1):1-8.

46. Walter A, Etienne-Selloum N, Brasse D, Schleiffer R, Bekaert V, Vanhoutte PM, Beretz A, Schini-Kerth VB: Red wine polyphenols prevent acceleration of neovascularization by angiotensin II in the ischemic rat hindlimb. J Pharmacol Exp Ther 2009, 329(no. 2):329-699.

47. Mariod A, Matthäus $B$, Hussein $\mid \mathrm{H}$ : Antioxidant activities of extracts from Combretum hartmannianum and Guiera senegalensis on the oxidative stability of sunflower oil. Emir J Food Agric 2006, 18(2006):20-28.
48. Ali H, König GM, Khalid SA, Wright AD, Kaminsky R: Evaluation of selected Sudanese medicinal plants for their in vitro activity against hemoflagellates, selected bacteria, HIV-1-RT and tyrosine kinase inhibitory, and for cytotoxicity. J Ethnopharmacol 2002, 83(3):219-228.

49. Gotink KJ, Verheul HM: Anti-angiogenic tyrosine kinase inhibitors: what is their mechanism of action? Angiogenesis 2010, 13(1):1-14.

50. Faivre S, Demetri G, Sargent W, Raymond E: Molecular basis for sunitinib efficacy and future clinical development. Nat Rev Drug Discov 2007, 6(9):734-745.

51. Wilhelm S, Carter C, Lynch M, Lowinger T, Dumas J, Smith RA, Schwartz B, Simantov R, Kelley S: Discovery and development of sorafenib: a multikinase inhibitor for treating cancer. Nat Rev Drug Discov 2006, 5(10):835-844

52. Patel PH, Chaganti RS, Motzer RJ: Targeted therapy for metastatic renal cell carcinoma. Br J Cancer 2006, 94(5):614-619.

53. Ibrahim B, A.E.-S, Saleh H: Phytochemical Investigation of Nicotiana glauca and Microbial Degradation of Nicotine as a Water Pollutant of Tobacco. Fairford, GLO, United Kingdom: LAP LAMBERT Academic Publishing; 2012.

54. Hassan LEA, M.B.K.A, Majid ASA, lqbal MA, Al Suede FSR, Haque RA, Ismail Z, Ein OC, Majid AMSA: Crystal structure elucidation and anticancer studies of (-)-pseudosemiglabrin: a flavanone isolated from the aerial parts of tephrosia apollinea. PLOS ONE 2014, 9(3):90806.

55. Dai Z-J, Lu WF, Gao J, Kang HF, Ma YG, Zhang SQ, Diao Y, Lin S, Xi-Jing W, Wu WY: Anti-angiogenic effect of the total flavonoids in Scutellaria barbata D. Don. BMC Complement Altern Med 2013, 13(1):1-10.

56. Abou-Douh AM, I.C, Toscano RA, Nariman N, El-Khrisy E: Prenylated flavonoids from the root of Egyptian Tephrosia apollinea-crystal structure analysis. Z Naturforsch 2005, B 60:458-470.

57. Abouzid S, Sleem A: Hepatoprotective and antioxidant activities of Tamarix nilotica flowers. Pharm Biol 2011, 49(4):392-395.

58. Nawwar MAM, Buddrus J, Bauer H: Dimeric phenolic constituents from the roots of Tamarix nilotica. Phytochemistry 1982, 21(7):1755-1758.

59. Barakat $\mathrm{HH}$, Nawwar MA, Buddrus J, Linscheid M: Niloticol, a phenolic glyceride and two phenolic aldehydes from the roots of Tamarix nilotica. Phytochemistry 1987, 26(6):1837-1838.

60. Folkman J: Angiogenesis and apoptosis. Semin Cancer Bio/ 2003, 13(2):159-167.

61. Tiwari M: Apoptosis, angiogenesis and cancer therapies. J Cancer Ther Res 2012, 1(1):3.

\section{doi:10.1186/1472-6882-14-406}

Cite this article as: Hassan et al:: Correlation of antiangiogenic, antioxidant and cytotoxic activities of some Sudanese medicinal plants with phenolic and flavonoid contents. BMC Complementary and Alternative Medicine 2014 14:406.

\section{Submit your next manuscript to BioMed Central and take full advantage of:}

- Convenient online submission

- Thorough peer review

- No space constraints or color figure charges

- Immediate publication on acceptance

- Inclusion in PubMed, CAS, Scopus and Google Scholar

- Research which is freely available for redistribution 